Volkov R. K., Tolokova T. I., Vadziuk N. S. Clinically pathogenic aspects of the comprehensive treatment of burn scars. Journal of Education, Health and Sport. 2020;10(9):988-1000. eISSN 2391-8306. DOI http://dx.doi.org/10.12775/JEHS.2020.10.09.118 https://apcz.umk.pl/czasopisma/index.php/JEHS/article/view/JEHS.2020.10.09.118

https://zenodo.org/record/4290924

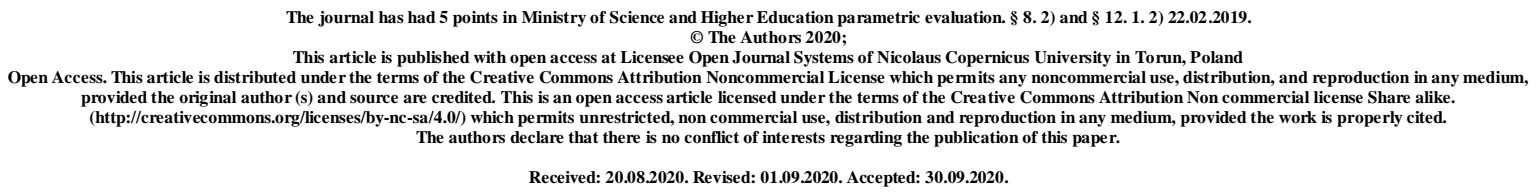

UDC: 617-001.17-003.92-08

\title{
CLINICALLY PATHOGENIC ASPECTS OF THE COMPREHENSIVE TREATMENT OF BURN SCARS
}

\author{
R. K. Volkov ${ }^{1}$, T. I. Tolokova ${ }^{1}$, N. S. Vadziuk ${ }^{2}$ \\ ${ }^{1}$ I. Horbachevsky Ternopil National Medical University \\ ${ }^{2}$ State Institution 'Institute of Traumatology and Orthopedics' of National Academy of \\ Medical Sciences of Ukraine
}

\begin{abstract}
Any deformities of general anatomical organization of the tissue at gradual deprivation of function can be relegated to the wounds which are relative to the pain syndrome and functional abnormality of the affected area of the body and cosmetic defects except for psycho-emotional disorders and they are also economic burdens for patients, their families and society. Thus short-term wound healing of high quality has high clinical value as it may lead to reduction in hospitalization and coming-back to the performance capability of patients [1]. Dermal wound healing is a dynamic and highly adjustable process of cellular, humoral and molecular mechanisms which starts after the injury and it may last for years. The correlation of cells, growth promoting substances and cytokines ends with wound healing even if a sensitive balance between cells and mediators may be imperfect, the results of the investigative procedure shows that deficit of cellular factor or mediator can be compensated with other components which take part in wound healing, thus the reactivation may still take place. An inflammatory reaction is certain under the physiologic wound healing: cell lines, functions and mediators [2]. The understanding of the sequence and chronology of processes
\end{abstract}


of the wound healing, particularly the evolution of growth promoting substance and cytokine effects which leads to cell and tissue changes which are necessary for reparative processes, (Simpson and Ross, 1972; Leibovich and Ross, 1975) physiologic spatiotemporal changeability of sequential leucocyte form is shown by experiments (Martin 1997; Singer and Clark, 1999) and also the effect of competently selected corrective measures lets us achieve maximum impact of medical treatment.

Suggested compound method of correction of burn scars which combines cryosurgical method with xenotransplantation, injections of steroids in scars, laser genesis procedures and compression clothes with silicone plates guarantees high efficiency of treatment of burn scars.

\section{Keywords: keloid scars; hypertrophic scars; cryodestruction;} xenotransplantation; laser genesis.

Introduction. As far as is known, regenerative process resides in the specific tissue replacements which were injured by corrosive influence, more specifically skin turn over defines nonspecific healing and the wound is healed with fibrosis and scarring. Unfortunately, the last ones represent the main form of cutaneous wound healing [3].

A scar is in progress because of the replacing its own tissues with the connective one and it has the form of heavy mass which originates from the tissue regeneration as a result of different injuries where the main anatomical element is collagen fibers. The triggers of keloid scars in modern medicine continue being reasons of the scientific inquiry of researchers [4]. Doctors suppose that such damages are caused by a particular predisposition which may have genetic basis $[5,6]$. The investigation in vitro showed that neutrophils, which are discharged from the wound healing locus, may modulate the expression of the phenotype and cytokine profile of the macrophages while also regulating genuine immunoreation in a time of healing (Daley et al., 2005). Hyperchromatism of skin care and also wounds in particular parts of the body which are typical before keloids appear particularly on an earlobe, breast, upper back and deltoid muscle zone refer to the risk factors of keloid onset. But on the whole keloid and hypertrophic scars may appear anywhere including a face and hairy part of the head. Mostly keloid scars are formed under the wound healing which appeared in adolescence life and during pregnancy. It is a complicated task to predict the risk of the progression of such changes in skin.

According to scientists, the occurrence of burn damage within all types of injury comes out at 5,6 - $12 \%$, approximately 50000 people in Ukraine experience of burns annually [7]. Thermal injuries of different severity levels result from the strength and kind of 
actions of thermal agent on skin and their healing often lead to formation of scar deformities which are late burn complications. Cutaneous wound healing takes place thanks to a special mechanism of cascade cellular integrity which is unique in itself. The regenerative process of integration of skin cover always takes place because of the scarring at burning injury with the disorganization which is deeper than the papilliform dermis [8, 9, 10, 11].

The pattern of pathological changes which goes with burn disease occurs in reaction to the effect of thermal factor in a body [12].

A lot of different publications of study outcome of the processes of thermal wound healing and elaboration of scars don't demonstrate a shared vision toward the mechanism of occurrence and anatomic constitution of abnormal scars. Scar deformities after burns is indicated in $21-50 \%$ of convalescents and more than a half of them are people of working age and children [13].

Scar treatments, which are induced by a burning injury during post-hospital rehabilitation, are based on conservative therapy and operative methods [12].

The term of the termination of the elaboration of scars has special significance in clinical practice and it lasts for about a year after the action of thermal agent. Conservative therapy is the most effective during this time period. According to the literature, the treatment of scar deformities and contractures, which occur on different parts of a body after skin burns, refers to the closing stage of the rehabilitation system $[14,15,16]$

Objective of the work. The aim of the study was to find out ways to improve and substantiate comprehensive treatment of the patients with scar deformities after burns, substantiate the differentiated approach to the decision-making process of medical-preventive activities according to pathogenesis of scar deformities and their morphology.

Materials and methods. The survey showed the results of medical-preventive activities in three groups of patients ( $\mathrm{n}=89$, table1):

1) silicone plates were exhibited in the first group $(n=49)$, produced by PLC "Institute of Biomedical Technology" (Ternopil, Ukraine), attached to the location of lesion with compression clothes sewn on the individual basis USS ISO 13485:2005; EN ISO 13485:2012 [Institute of Biomedical Technology].

Depending on different period of time after wound healing the first group was divided into 2 subgroups: subgroup $\mathrm{A}(3-5$ days after epithelialization, $\mathrm{n}=30)$ and subgroup $\mathrm{B}(20-30$ days after epithelialization, the initial stage of scar formation, $n=19$ );

$2)$ in the second group $(n=16)$ of patients with old (1-3 years after burns) hypertrophic and keloid scars cryodestruction was put into practice which was banded with the 
xenotransplantation of the wound on the first or second day after the cryodestruction (the method of the professor Bihuniak V. V., www.ibt.in.ua) and combined with injections into the scar tissue of diprospan at the rate of $0.2 \mathrm{ml} / 1 \mathrm{~cm}^{2}$ of scar once a month;

3) In patients of the third (control group, $n=24$ ) an excision of scar defect was performed in other medical institutions without prevention of pathologic scar recurrence.

To reduce the manifestations of the inflammatory process in the skin, coagulation of dilated capillaries and, accordingly, the correction of red color in areas of scars, 49 patients from the first and second groups received a course of procedures of laser genesis by $\mathrm{Nd} \mathrm{Yag}$ 1064 nm (Cutera Xeo platform, RS MON of Ukraine N 13157/2013, "Mone clinic” Ternopil, Ukraine).

It was given consideration to the absence of contraindications for comprehensive treatment forming groups of patients to provide treatment (virulent diseases, gastroduodenal ulcer, diabetes mellitus, cancer, mental disorders and neurological diseases, chronic infections, people over 60, pregnancy and breast feeding, infancy, general diseases and pathological conditions of the body which are contraindications to use corticosteroids, timelapse regenerative process).

The authors stuck to the ethical norms working on biomedical testing.

Table 1. Disposition of patients according to treatment

\begin{tabular}{|c|c|c|c|c|c|}
\hline \multirow{2}{*}{$\begin{array}{l}\text { Methods of treatment } \\
\text { and prevention }\end{array}$} & \multicolumn{2}{|c|}{ Group 1(n=49) } & \multirow{2}{*}{$\begin{array}{c}\text { Group } 2 \\
(n=16)\end{array}$} & \multirow{2}{*}{$\begin{array}{c}\text { Group } 3 \\
\text { (control) } \\
(\mathrm{n}=24)\end{array}$} & \multirow{2}{*}{$\begin{array}{c}\text { Total } \\
(\mathrm{n}=89)\end{array}$} \\
\hline & $\begin{array}{c}\text { subgroup A } \\
(\mathrm{n}=30)\end{array}$ & $\begin{array}{c}\text { subgroup B } \\
(\mathrm{n}=19)\end{array}$ & & & \\
\hline \begin{tabular}{|l} 
silicone plates + \\
compression clothes
\end{tabular} & 30 & 19 & 16 & - & 65 \\
\hline $\begin{array}{l}\text { Cryodestruction with } \\
\text { xenotransplantation }+ \\
\text { Diprospane }\end{array}$ & - & - & 16 & - & 16 \\
\hline Laserogenesis & 25 & 12 & 12 & - & 49 \\
\hline Excision of scars & - & - & - & 24 & 24 \\
\hline
\end{tabular}

Morphological and immunohistochemical research of scars after excision was conducted.

The examination of patients started with the summative assessment of the external view of the scar. "The Universal Scale of the Assessment of Postburn Scars" was used for it 
(Fistal N. M.) which is a modification of a famous Vancouver Scar Scale, the most important symptoms were included there (table 2).

Table 2. The universal scale of the assessment of postburn scars [17]

\begin{tabular}{|c|c|c|c|}
\hline № & Feature & Method & Number of points \\
\hline 1 & 2 & 3 & 4 \\
\hline 1 & Scar thickness & $\begin{array}{l}\text { Identification of the } \\
\text { scar level above the } \\
\text { surface of healthy skin }\end{array}$ & $\begin{array}{l}0 \text { - on the level of healthy skin; } \\
1 \text { - up to } 1 \mathrm{~mm} \text { above the level of healthy skin; } \\
2 \text { - up to } 2 \mathrm{~mm} \text { above the level of healthy skin; } \\
3 \text { - from } 2 \text { to } 5 \mathrm{~mm} \text { above the level of healthy } \\
\text { skin; } \\
4 \text { - more than } 5 \mathrm{~mm} \text { above the level of healthy } \\
\text { skin; }\end{array}$ \\
\hline 2 & $\begin{array}{l}\text { Uniformity of } \\
\text { the scar } \\
\text { thickness }\end{array}$ & $\begin{array}{l}\text { Identification of the } \\
\text { uniformity of the scar } \\
\text { thickness on its whole } \\
\text { surface }\end{array}$ & $\begin{array}{l}0-\text { equal thickness; } \\
1-25 \% \text { of the scar areal has unequal } \\
\text { thickness; } \\
2-50 \% \text { of the scar areal has unequal } \\
\text { thickness; } \\
3-75 \% \% \text { of the scar areal has unequal } \\
\text { thickness; } \\
4 \text { - unequal thickness of the whole scar; }\end{array}$ \\
\hline 3 & $\begin{array}{l}\text { Vascularizatio } \\
\mathrm{n} \text { of the scar }\end{array}$ & $\begin{array}{l}\text { Identification of the } \\
\text { scar colour according to } \\
\text { its vascularization } \\
\text { degree }\end{array}$ & $\begin{array}{l}0 \text { - colour of uninjured skin; } \\
1 \text { - pink colour of the scar; } \\
2 \text { - red colour of the scar; } \\
3 \text { - crimson and cyanotic colour of the scar; }\end{array}$ \\
\hline 4 & $\begin{array}{c}\text { Chromatism of } \\
\text { the scar }\end{array}$ & $\begin{array}{l}\text { Identification of the } \\
\text { chromatism existence } \\
\text { in scar tissue }\end{array}$ & $\begin{array}{l}0 \text { - normal pigmentation of the scar; } \\
1 \text { - hypo-pigmentation of the scar; } \\
2 \text { - multimodal pigmentation of the scar; } \\
3 \text { - hyper-pigmentation of the scar; }\end{array}$ \\
\hline 5 & $\begin{array}{c}\text { Consistency of } \\
\text { the scar }\end{array}$ & $\begin{array}{c}\text { Identification of } \\
\text { tightness and lability of } \\
\text { tissue scar }\end{array}$ & $\begin{array}{l}0 \text { - scar fold; } \\
1 \text { - scar fold by force; } \\
2 \text { - indurated and slow-moving; } \\
3 \text { - indurated and moveless; }\end{array}$ \\
\hline 6 & $\begin{array}{l}\text { Ulceration of } \\
\text { the scar }\end{array}$ & $\begin{array}{c}\text { Identification of } \\
\text { ulcerative defect on the } \\
\text { scar surface }\end{array}$ & $\begin{array}{l}0 \text { - there are no ulcerations; } \\
1 \text { - ulceration in the stage of healing; } \\
2 \text { - long-lasting ulceration; } \\
3 \text { - advanced ulceration; }\end{array}$ \\
\hline 7 & $\begin{array}{c}\text { Temperature of } \\
\text { the scar }\end{array}$ & $\begin{array}{l}\text { Identification of the } \\
\text { scar temperature with } \\
\text { the help of an } \\
\text { indicating thermometer } \\
\text { and comparing it with } \\
\text { the temperature of } \\
\text { healthy skin }\end{array}$ & $\begin{array}{l}0 \text { - is aligned with the temperature of adjacent } \\
\text { uninjured skin; } \\
1 \text { - below the temperature of adjacent uninjured } \\
\text { skin; } \\
2 \text { - up by } 0,5^{\circ} \mathrm{C} \text {; } \\
3 \text { - up by } 1^{\circ} \mathrm{C} ;\end{array}$ \\
\hline 8 & $\begin{array}{l}\text { Intense itching, } \\
\text { paresthesia of } \\
\text { the scar }\end{array}$ & $\begin{array}{l}\text { Identification of specify } \\
\text { symptoms of patients } \\
\text { and existence of scar } \\
\text { excoriation }\end{array}$ & $\begin{array}{l}0 \text { - there are no symptoms; } \\
1 \text { - mild and unsteady; } \\
2 \text { - steady; } \\
3 \text { - evident; }\end{array}$ \\
\hline
\end{tabular}




\begin{tabular}{|c|c|c|l|}
\hline 1 & \multicolumn{1}{|c|}{2} & 3 & \multicolumn{1}{c|}{4} \\
\hline 9 & $\begin{array}{c}\text { Progression of } \\
\text { the scar }\end{array}$ & $\begin{array}{c}\text { Identification of the } \\
\text { progression of the scar } \\
\text { using interview and } \\
\text { monitoring }\end{array}$ & $\begin{array}{l}0 \text { - there is no progression; } \\
1 \text { - weak progression of the scar; } \\
2 \text { - moderate progression of the scar; } \\
3 \text { - fast progression of the scar; }\end{array}$ \\
\hline 10 & Sensitivity & $\begin{array}{c}\text { Comparison of } \\
\text { Sensitivity } \\
\text { (temperature, algetic, } \\
\text { haptic) of a scar and } \\
\text { adjacent uninjured skin }\end{array}$ & $\begin{array}{l}0 \text { - there is no difference in vulnerability; } \\
1 \text { - over-the-top; } \\
2 \text { - impaired; } \\
3\end{array}$ \\
\hline
\end{tabular}

Total points were determined during the primary inspection (maximally - 32), the state of a scar tissue was taken to the report and pictures were taken too. The second examinations were held in 2 and 4 months after the completion of treatment procedures, total points were estimated and compared with the previous number.

Cryodestruction is provided in "Mone clinic" (Ternopil, Ukraine) with the help of the cryosurgical apparatus “Krioton-3” (RS MOH of Ukraine № 14917/2015) on one-to-one basis depending upon the term of wound epithelialization.

Injection of Diprospan (betamethasone) into the scar tissue at the rate of $0.2 \mathrm{ml} / 1 \mathrm{~cm}^{2}$ of scar once a month was carried out into dermis where collagenase was organized.

The investigation is up to current quality of moral and ethical standards due to the regulation of legislative acts of Ukraine. The protocol of a session of committee of bioethics TNMU № 59 on June 5, 2020.

Statistical processing of substances was provided with the use of a batch program Statistica 6.0 (Statsoft, USA) and MedCale.

\section{Results and discussion}

Special silicone plates which are intended for sticking on a keloid scar were used for 49 patients who set up the first group. Mechanical compression of affected area of the skin was provided by ensuring physiologically adequate level of compressive exposure according to individual quantitative and qualitative systemic criterion which were taken into consideration at the technical stage of producing clothes and later were taken on other stages of clinical use.

The mechanism of action of silicone plates when combined with compressive clothes at the early stages of scar formation is about originating ischemia of connective-tissue part of the scar and involution of interstitial edema and amount of capillary tubes. It leads to reducing the mass of connective tissue, precipitation of the conduct of inflammation process and growth of scar tissue. At an advanced stage of the scar existence hypoxia leads to 
degenerative changes of fibroblasts which pass into advance and quiescent forms and it reduces producing of collagen and weight of scar tissue. Collagenous fibers under the influence of external pressure fine away and get well-ordered position running parallel with each other and skin surface $[9,18,19,20,21]$.

According to our data combination of compression clothing with silicone plates designed to treat keloid and hypertrophic scars gave excellent results in $19(63,33 \%)$ patients of subgroup A.

In $9(30 \%)$ patients of subgroup A there was an active inflammatory process, manifested by increased vascularization and bright pink color of the skin during the first two months. After a course of laser genesis procedures, the indicators of pathological vascularization of the scar area decreased by $85 \%$.

Two patients $(6,67 \%)$ of subgroup A appeared hypertrophic scars, which led to minor cosmetic defects of the skin.

In subgroup B the results were excellent in 7 patients $(36,84 \%)$. There were 4 cases when treatment was ineffective $(21,05 \%)$. A clinical examination of 19 patients of subgroup B was performed using a universal scale. 2 and 4 months after the start of the use compression clothing with silicone plates, a repeated clinical examination of scar tissue was performed. The results obtained are presented in table 3 .

Table 3. Distribution of signs of scars during treatment

\begin{tabular}{|l|l|l|l|l|}
\hline \multirow{2}{*}{ № } & \multirow{2}{*}{ Signs of a scar $(\mathbf{n}=\mathbf{1 9})$} & \multicolumn{3}{|l|}{ Number of points $(\mathbf{M} \pm \mathbf{m}, \boldsymbol{\%})$} \\
\cline { 3 - 5 } & & $\begin{array}{c}\text { Before } \\
\text { treatment }\end{array}$ & In 2 months & In 4 months \\
\hline 1 & Scar thickness & $2,44 \pm 0,18$ & $2,11 \pm 0,24$ & $1,33 \pm 0,23$ \\
\hline 2 & $\begin{array}{l}\text { Uniformity of the scar } \\
\text { thickness }\end{array}$ & $1,39 \pm 0,30$ & $1,39 \pm 0,30$ & $0,67 \pm 0,18$ \\
\hline 3 & Vascularization of the scar & $2,00 \pm 0,18$ & $1,78 \pm 0,17$ & $0,83 \pm 0,19$ \\
\hline 4 & Chromatism of the scar & $0,67 \pm 0,27$ & $0,67 \pm 0,27$ & $0,67 \pm 0,27$ \\
\hline 5 & Consistency of the scar & $1,17 \pm 0,26$ & $1,06 \pm 0,22$ & $0,61 \pm 0,18$ \\
\hline 6 & Ulceration of the scar & $0,22 \pm 0,10$ & 0 & 0 \\
\hline 7 & Temperature of the scar & $1,44 \pm 0,27$ & $0,83 \pm 0,19$ & $0,11 \pm 0,11$ \\
\hline 8 & $\begin{array}{l}\text { Intense itching, paresthesia } \\
\text { of the scar }\end{array}$ & $2,00 \pm 0,18$ & $1,39 \pm 0,18$ & $0,61 \pm 0,14$ \\
\hline 9 & Progression of the scar & $1,67 \pm 0,16$ & $0,89 \pm 0,14$ & $0,28 \pm 0,11$ \\
\hline 10 & Sensitivity & $0,83 \pm 0,17$ & $0,83 \pm 0,17$ & $0,28 \pm 0,16$ \\
\hline
\end{tabular}

The sum of points on the average before the beginning of treatment was 13,83 , in 2 months $-10,9$, in 4 months of use of silicone plates - 5,39 points. The amount of points after 
treatment decreased by 2.6 times, which indicates a significant effectiveness of this method of treatment.

The effect of using of silicone plates was manifested by softening, flattening and reducing the volume of scar tissue, approximation of skin color to natural, increasing the level of elasticity of scar tissue, reducing the height of the scar relative to the level of healthy skin.

In the second group of patients $(n=16)$ there was used a multidimensional approach to correct burn scars which consisted of cryodestruction with xenotransplantation of the wound on the first or second day after cryodestruction (the method of the professor Bihuniak V. V.) and was combined with injections of diprospan in a scar tissue.

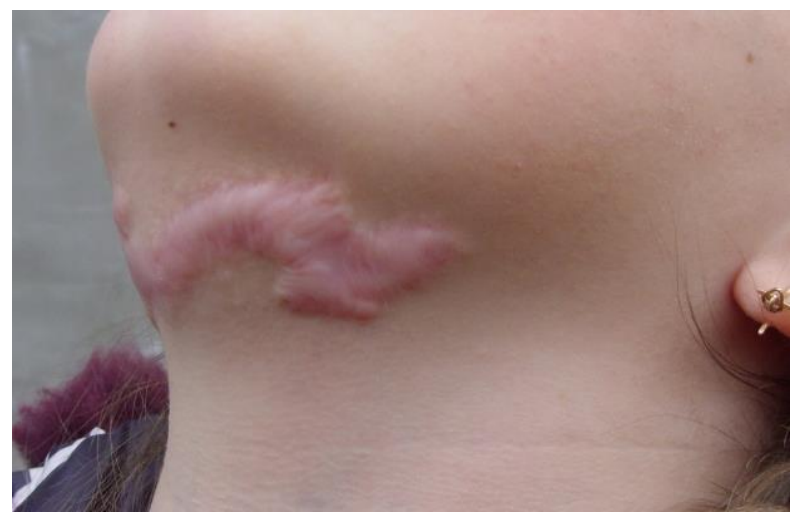

Figure1. Keloid postburn scar before treatment

The method of cryodestruction has been applied for 30 years by the professionals of the "Mone clinic" (Ternopil, Ukraine). Cryodestruction is like controlled frostbite with liquid nitrogen gas of paraplasm on the skin involving cells and capillary tubes and another dysdiemorrhysis which leads to thrombosis and cellular anoxia, necrosis and tissue breakdown. A day or two days after cryodestruction a bulla appears which is full of clear liquid on the area which is treated (Figure 2).

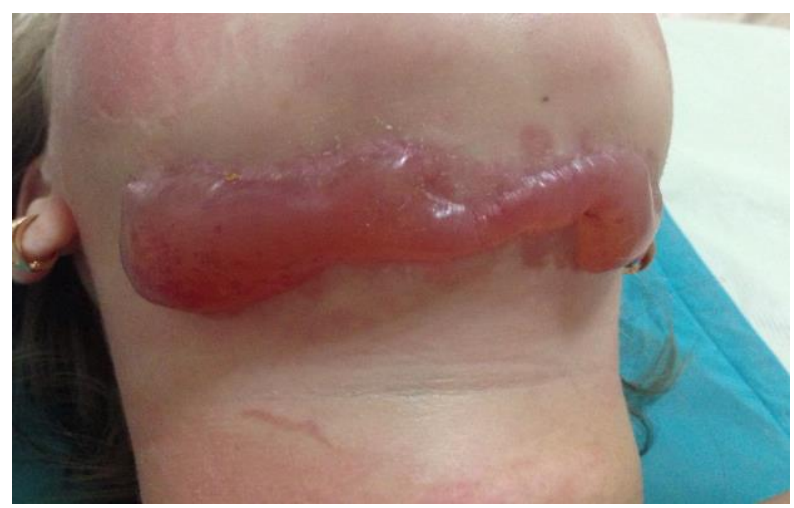

Figure 2. Scar tissue after cryodestruction 
On the second full day a bulla is removed with serous fluid in the area of freezing, there were applied pieces of xenografts on the newly made wound (Figure 3).

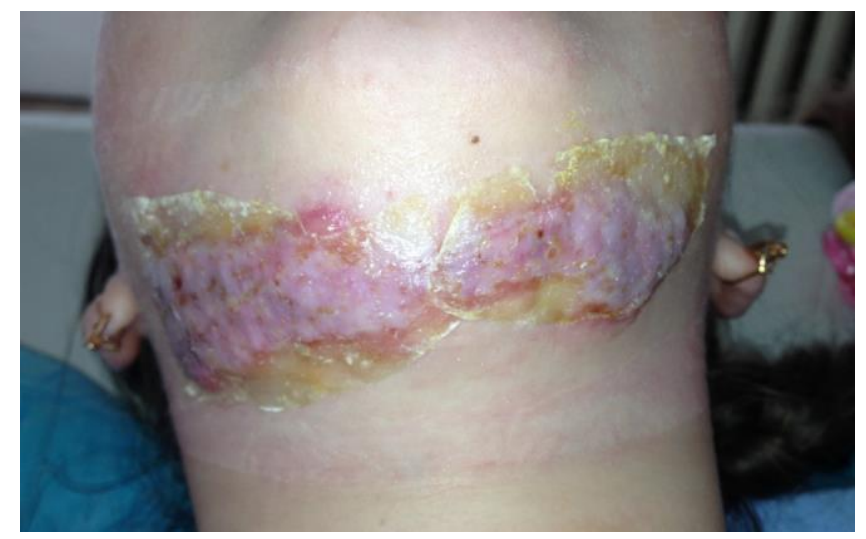

Figure 3. Scar tissue after xenotranplantation

The right healing applying new technologies of conducting biological regenerative process leads to satisfactory results in 11 patients of the second group $(68,75 \%)$. In patients of the second group who received a comprehensive treatment of scars there was softening, reduction in size and volume, flattening, lightening of the scars. In place of the scar remains spot that is not above the level of the skin, gradually acquires the color of healthy skin, disappears unpleasant pain and itching, significantly increases the elasticity of connective tissue, reduces swelling. Figure 4 shows that it has been objectively confirmed that the scar reduces its height up to $70 \%$.

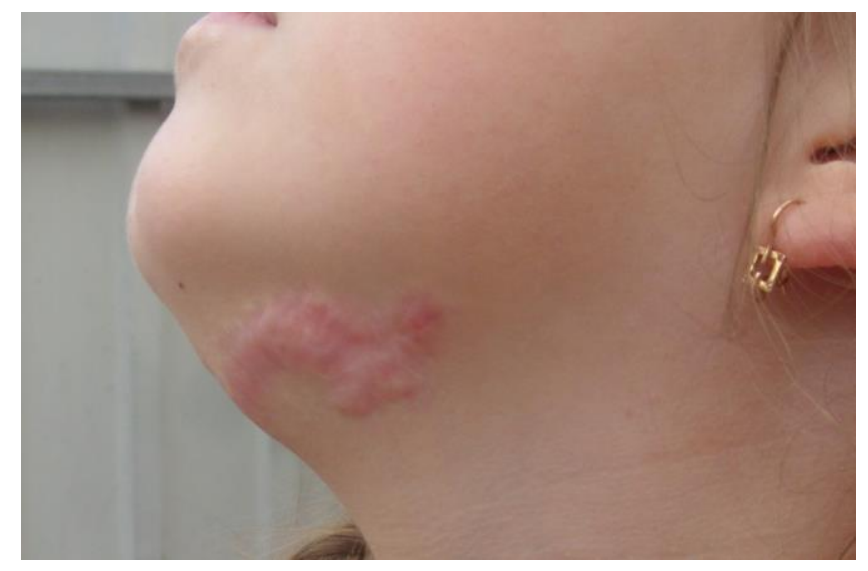

Figure 4. Scar tissue after the first procedure 
In between stages of cryodestruction process we applied injections of steroids in scars for treatment keloid and hypertrophic scars to achieve complete recovery of the colour and structure of the skin in the area of the scar.

Steroid hormones were applied for anti-inflammatory, anti-allergic, anti-exudative, antipruritic action, which in our opinion is especially useful after controlled cryodestruction. They block cytokine release out of lymphocytes and macrophages; repress the exposure of inflammation mediators by eosinophils (interleukins and alpha interferon); block appearance of endothelial growth promoting substance and tumour necrosis factor, stop dissection of fibroblasts which disorder connective tissue and at the same time take part in healing by a process of wound healing and formation of scar tissue; reduce the amount of mast cells which take part in establishment of hypersensitivity reactions by a process of histamine release in case of contact with antigenic protein. These medications reduce cellular inflammable infiltrate, decline migration of leukocytes and lymphocytes at infiltration of medicinal substance. Applied steroids lower fusion of collagen not only by the effect of distress of dissection of fibroblasts but because of increase of concentration of collagenase which is an enzyme that splits collagen $[21,22]$

Injection therapy of keloid and hypertrophic scars by glucocorticosteroids was applied with diprospan $0.2 \mathrm{ml} / 1 \mathrm{~cm} 2$ of scar once a month in patients with advanced keloid and old hypertrophic scars in patients of the second group after cryodestruction and xenotransplantation. Steroids were applied locally using intrascarring injections. Efficiency of comprehensive treatment for those patients who were treated old burn scars is up to $90 \%$ in the time of 3 months (Figure 5).

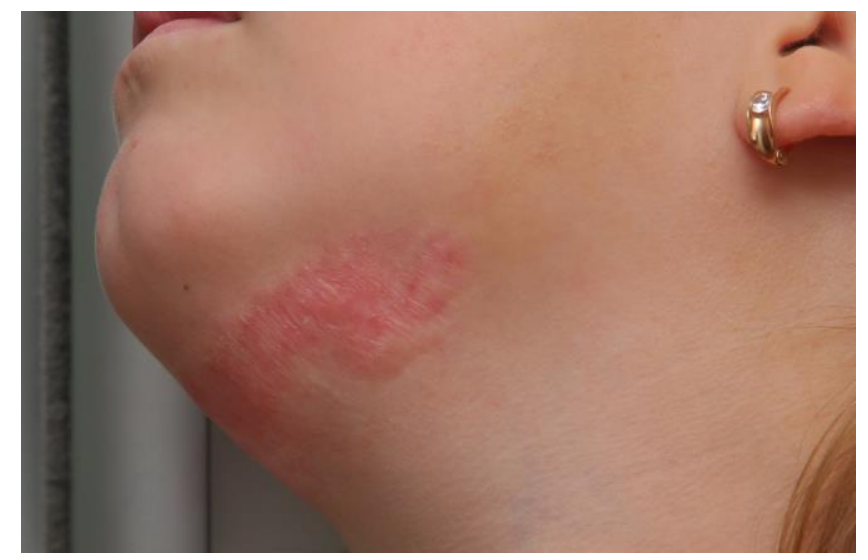

Figure 5. Scar tissue after two procedures (complete arborization of the scar height) 
In $4(25 \%)$ patients there was an active inflammatory process, manifested by increased vascularization and bright pink color of the skin during the first two months. After a course of laser genesis procedures, the indicators of pathological vascularization of the scar area decreased by $80 \%$. Recrudescence was identified in $6,25 \%$ of patients, these are only 1 example and it is lower than applying injectable monotherapy [23, 21, 24, 25]

An excision of scar defect was performed for patients of the control group $(n=24)$ in other medical institutions without prevention of pathologic scar recurrence. Recurrence of pathological scars occurred in 20 patients (83,33\%): in 14-keloid and 6-hypertrophic. Normotrophic scars were formed in $4(16,67 \%)$ patients, but with existing pathological vascularization in the areas of postoperative scars.

Properly planned numerous methods of treatment of burn scars and performed due to up-to-date standards guarantee high performance. However, there isn't any shared vision concerning functional comprehensible correctional technique which speaks for actuality and incomplete state of knowledge of reachability problem of necessary treatment effect.

\section{Conclusions}

Findings. As can be seen from the above, the suggested compound method of correction of burn scars which combines cryosurgical method with xenotransplantation, injections of steroids in scars, laser genesis procedures and compression clothes with silicone plates guarantees high efficiency of treatment of burn scars.

In most cases of treatment approaches there is necessity to combine two or more methods of correction and apply them in incremental steps according to scar growth.

It's better to start treatment and correction straight after the injury at the stage of scar formation. The sooner treatment starts, the better and more qualified anatomic and functional structure of affected area recovers.

When there is no qualified treatment or there is untimely onset of it, uncontrolled scar growth may start, deformity of connective tissue may progress, contracture with significant abnormality of functionality of affected area and recrudescence after the correction.

It was clinically and morphologically concluded high efficiency of applying silicone plates, compression therapy, cryosurgical method, xenotransplantation, applying injection of steroids and laser genesis in the multidimensional approach to treat pathological scars after burns. 


\section{Reference}

1. Lazarus GS, Cooper DM, Knighton DR, Percoraro RE, Rodeheaver G, Robson MC: Definitions and guidelines for assessment of wounds and evaluation of healing. Wound Repair Regen 1994; 2: 165-170. https:

2. Eming SA, Krieg T, Davidson JM: Inflammation in wound repair: molecular and cellular mechanisms. J Invest Dermatol 2007; 127: 514-525

3. Krafts KP: Tissue repair: the hidden drama. Organogenesis 2010; 6: 225-233

4. Gladstone, H.B., Berg, D., \& McDonald, M. (2010). Scar revision. Dermatology Research and Practice, 2010, 545796. doi: 10.1155/2010/545796.

5. Stuart E Turvey, David H Broide Innate immunity The Journal of allergy and clinical immunology 125(2 Suppl 2):S24-32 2009 ;

6. Amanda MacLeod, Jonathan N. The Innate Immune System in Acute and Chronic Wounds Advances In Wound Care, Volume 5:65-78;

7. Kozynets H. P., Zhernov O. A., Zhernov A. O. Postburn scars, pathogenesis and methods of conservative treatment. Plastic and reconstructive surgery No 3-4, 2014. pp. $13-23$

8. Abaev Y. K. Handbook of Surgery. Wounds and wound infection / Y. K. Abaev. - Rostov-on-Don: Feniks, 2006. - P. 427.

9. Belousov A. E. Scars and their correction / A. E. Belousov. - SPb.: Komandor-SPB, 2005. - 123 p.

10. Hlubokova I. B. Some aspects of postburn wound healing / I. B. Hlubokova // Annals of mergency and rehabilitation medicine. -2006. - T. 7, No 3. - P. 493.

11. J.M. Reinke H. Sorg Wound Repair and Regeneration Eur Surg Res 2012;49:35-43].

12. Burning Injury and Its Consequences. Guideline for Practitioners/ Endorsed by Kozynets H. P., Sliesarenko S. V., Sorokina O. Y., Klyhunenko O. M., Tsyhankov V. P. Dnipropetrovsk, edition "Press of Ukraine" 2008. - P. 224.

13. Mateev M. A. Remodelling Management of Postburn Scar Deformities in Children / M. A. Mateev, H. C. Shaltakova // Pediatric Surgery. - 2009. - No 1. - P. 38-39

14. Methods of Conservative and Operative Rehabilitation of Surgical Patients with consequences of burns // H. P. Kozynets [and others]. - K.: SP "International PressPolygraph Service", 2010. - P. 100.

15. Polukarov N. Modern Methods of Pathological Scar Treatment and Scars Complications / N. Polukarov, V. Holubev // Doctor. - 2007. - No 2. - P. 59 - 62. 
16. Pavlovych V. A. Treatment Practice and Preventive Measures of Keloid and Hypertrophic Scars in the Area of Face and Neck / V. A. Pavlovych, V. M. Ezrokhyn // Stomatology. - 2008. - No 2. - P. 46-49.]

17. Fistal N. M.) [ Ukrainian medical journal. Key considerations of clinical practice. №2(52) III - IV 2006

18. Alekseev A. A. Rehabilitation of Burn Sufferers / A. A. Alekseev, P. V. Saryhyn, S. V. Popov // Plastic Surgery: National Congress Material (Moscow, June 8-10 2011). - M.: OOO "Bionika Publishing House". - 2011. - P. 13.

19. Problems of Diagnostic and Treatment of Pathological Scars / V. H. Myshalov, V. V. Khrapach, I. A. Nazarenko [and others] // Ukrainian Surgery. - 2008. - No 4. - P. 109114.

20. Preventive Measures and Therapy of Scars Process of Soft Tissues / O. A. Danylov, V. F. Rybalchenko, A. M. Uryn [and others] // Pediatric Surgery. - 2006. - T. 3, No 1(10). - P. 67-73.

21. Berman B., Flores F. The treatment of hypertrophic scars and keloids // Eur. J. Dermatol. - 1998. - Vol. 8, No 8. - P. 591 - 595.

22. Mutalik S. Treatment of keloids and hypertrophic scars / S. Mutalik // Indian J. Dermatol. Venereol. Leprol. - 2005. - Vol. 71, No 1. - P. 3-8.].

23. Correction of scars / under the editorship of K. A. Arndt; edition of the series of George J. Dover; translated from English under general editorship of V. A. Visarinova]. M.: OOO “Reed Elsevier”, 2009. - P. 101.;

24. Loannovich J., Panayotou R., Mantas N., Alexakis D. The treatment of burn scars: our experience. // Annals of MBC. - 1990. - Vol.3. - No 4. - P. 589 - 591.

25. Roseborough I. E. Prevention and treatment of excessive dermal scarring / I. E. Roseborough, M. A. Grevious, R. C. Lee // J. Natl. Med. Assoc. - 2004. - Vol. 96, No 1. - P. 108-116.] 